Paedagogia Christiana

I/29 (2012) - ISSN 1505-6872

Dorota Grabowska*

Toruń

\title{
Religie i religijność w świecie współczesnym, sekcja IX: Pedagogika religii, Toruń, 12-15 września 2011 roku
}

Pod hasłem Religie $i$ religijność w świecie współczesnym odbył się w dniach 12-15 września 2011 roku w Toruniu III Międzynarodowy Kongres Religioznawczy. Decyzja o jego zorganizowaniu zapadła w dniu 19 grudnia 2010 roku podczas posiedzenia członków Zarządu Polskiego Towarzystwa Religioznawczego. Celem Kongresu było przeprowadzenie wielowątkowych rozważań nad współczesną kondycją religii rozumianej jako zinstytucjonalizowany system wierzeń i religijnością człowieka, czyli jego gotowością do wychodzenia naprzeciw temu, co ponad.

Podczas czterodniowych obrad zaplanowano cztery sesje plenarne: $R e-$ ligia i religijność w kulturze współczesnej, Religia w społeczeństwie, Teoria $i$ metody wspótczesnego religioznawstwa, Religioznawstwo w Polsce. Wystąpienia uczestników Kongresu zostały pogrupowane w trzynaście sekcji.

W dniu 13 września swoje obrady rozpoczęła sekcja Pedagogika religii. Jej koordynatorem został ks. prof. dr hab. Jerzy Bagrowicz a sekretarzem dr Jarosław Horowski. W pierwszej części wykładowej zatytułowanej Człowiek - religia - edukacja rozważania nad Trudnościami i szansami rozwoju pedagogiki religii w Polsce podjął ks. prof. Jerzy Bagrowicz. W wygłoszonym referacie skoncentrował się na przedstawieniu procesu odradzania się w dwudziestowiecznej Polsce pedagogiki religii i naukowej refleksji nad edukacją religijną, która inspirowana była chrześcijańską myślą wychowaw-

* Mgr Dorota Grabowska jest absolwentka historii i pedagogiki, doktorantką na Wydziale Nauk Pedagogicznych Uniwersytetu Mikołaja Kopernika w Toruniu. 
czą. Podkreślił znaczenie przemian polityczno-społecznych po 1989 roku dla rozwoju pedagogiki religii i jej naukowej refleksji. Następnie ks. prof. Zdzisław Pawlak swoje wystąpienie poświęcił Roli religii $w$ wychowaniu człowieka (aspekt filozoficzno-techniczny). Poprzez zdefiniowanie dwóch pojęć: religii i wychowania, wyeksponował tezę, że w wychowaniu człowieka skutecznie pomaga odwoływanie się do religii. Uznał, że religia pozwala na stworzenie integralnej wizji człowieka, który pochodzi od Boga i do Niego zmierza, natomiast wychowaniu dostarcza wzorów, modeli życia ludzkiego, a zarazem pomaga człowiekowi w jego dążeniu do pełnego rozwoju. $\mathrm{Na}$ temat Europeizacji kształcenia w perspektywie pedagogiki religii rozważał prof. Bogusław Milerski. Stwierdził, że współczesna edukacja w coraz większym zakresie zostaje podporządkowana kryteriom standaryzacji, unifikacji, wymierności i mierzalności. Tworzenie europejskiej przestrzeni edukacyjnej przyczyniło się do dehumanizacji kształcenia, czyli zatracenia humanum w procesie kształcenia.

Druga część obrad obywała się w czterech sekcjach. Sekcja A skoncentrowała się na problematyce religijnej w pedagogice. Jej moderatorem został ks. prof. Jerzy Bagrowicz. W ramach tej sekcji wygłoszonych zostało pięć referatów. Podczas pierwszego wykładu Rozum, mit i religia dr Maria Boużyk zastanawiała się, czy agnostycyzm jest postawą pobożną? Czy teizm jako teoria intelektualna może być wprowadzany w praktykę wychowawczą? Czy kategoria mitu pozwoli objąć doświadczenie religijne? Czym będzie pedagogika mitu dla przyszłych pokoleń? Na temat Pedagogiki osoby jako bytu religijnego wykład wygłosił dr Witold Starnawski. Dostrzegł, że religijność jest trwałym elementem natury istoty ludzkiej, ponieważ przejawia się w wielu sferach ludzkiego życia. Każda jednostka ludzka ma prawo do przeżywania i wyrażania swej religijności, zarówno w sferze życia społeczno-instytucjonalnego, jak i w procesie wychowania. Rozważania nad obecnością religii w pedagogice na podstawie teorii F. D. E. Schleiermachera, J. F. Herbarta i D. Bennera podjął dr Dariusz Stępkowski. Uznał, że religia zawiera się w pedagogice, gdyż podmiotem oddziaływania pedagogicznego jest człowiek, który stawia sobie pytania religijne dotyczące celu i sensu życia. Podkreślał, że religia nie może być traktowana jako pewna „przybudówka” ideologiczna w procesie wychowania. Związki myślenia ogólnopedagogicznego z religią oparł na teorii dwóch klasyków: F. D. E. Schleiermachera i J. F. Herbarta oraz współczesnego pedagoga ogólnego D. Bennera. Zagadnienie Rodzina a problem aktualizacji przyrodzonej religijności człowieka. W oparciu o M. A. Krapca realistyczna filozofię czlowieka poruszyła dr Barbara Kiereś. W swoim wystąpieniu ukazała religijność jako cnotę społeczną oraz jej obecność w relacjach rodzinnych (osobowych) oraz w procesie wychowania i samowychowania, a ostateczne spełnienie się religijności 
człowieka w wizji celu ostatecznego jego życia. O tezach aksjologicznonormatywnych w strukturze pedagogiki chrześcijańskiej rozprawiał dr Piotr Magier. W swoim referacie podjął próbę rekonstrukcji twierdzeń aksjologiczno-normatywnych, określając ich specyfikę, typy, funkcję oraz relację wobec tez opisowo-wyjaśniających.

Wokół edukacji religijnej w perspektywie historycznej prowadzono rozważania w sekcji B, którą kierowała prof. Władysława Szulakiewicz. Pierwszy wykład na temat Ideałów wychowawczych w klasztornych szkołach żeńskich w okresie potrydenckim do początków XIX wieku wygłosiła dr Anna Szylar. Poruszyła zagadnienie dotyczące wychowania dziewcząt w szkołach zakonnych od końca XVI do 1815 roku. Podkreśliła, że w obowiązującym programie nauczania obecny był duch katolicyzmu, a edukacja zmierzała do ukształtowania moralności i rozwinięcia pobożności oraz nauczenia wykonywania prac niezbędnych do prowadzenia gospodarstwa domowego. Dr Anna Szylar zwróciła uwagę także na zmiany, jakie następowały w wychowaniu dziewcząt. Związane one były z przejęciem nadzoru nad szkolnictwem przez władze świeckie, wprowadzeniem systemu klasowo-lekcyjnego oraz jednolitych programów nauczania. Obraz edukacji religijnej w polskich podręcznikach historii wychowania XIX i początków XX wieku przedstawiła dr Agnieszka Wałęga. Przedmiotem analizy uczyniła podręczniki opublikowane w drugiej połowie XIX wieku, przeznaczone dla uczniów galicyjskich seminariów nauczycielskich oraz późniejsze publikacje opracowane także dla studentów wyższych uczelni. Omawiając podręczniki historii wychowania, skoncentrowała się przede wszystkim na zakresie uwzględniania w tych opracowaniach problematyki edukacji religijnej i stosunku poszczególnych autorów do tego zagadnienia. Kolejny wykład wygłosiła dr Joanna Falkowska, która poruszyła zagadnienie Pierwiastka religijnego $w$ wychowaniu narodowym. Postulaty okresu autonomii galicyjskiej. Mówiła o miejscu religii w programach nauczania, wypowiedziach i pracach myślicieli II połowy XIX i początków XX wieku. Podkreśliła znaczenie religii w kształtowaniu postaw patriotycznych i budowaniu tożsamości narodowej. Wśród poruszonej problematyki znalazły się także zagadnienia związane z zaangażowaniem jednostki ludzkiej w przeżywanie uczuć religijnych, życiem zgodnym z doktryną Kościoła, znaczeniem czynów świadczących o postawie człowieka oraz problem nauki religii w szkole. Zagadnienie Obecności idei religijnych $w$ polskich koncepcjach pedagogicznych okresu międzywojennego podjęła prof. Władysława Szulakiewicz. W swoim wykładzie ukazała występowanie różnorodnych treści i kategorii, związanych z edukacją religijną w latach 1918-1939. Motywy religijne zajmowały ważne miejsce w projektach edukacyjnych polskiej myśli pedagogicznej tego okresu. Problematykę Edukacji religijnej dzieci i młodzieży szkolnej okresu międzywojennego 
w stużbie humanizacji życia społecznego przedstawiła dr Aldona Zakrzewska. Na początku podkreśliła znaczenie katolickiej doktryny wychowawczej w polskiej edukacji okresu międzywojennego oraz w procesie przywracania ładu społecznego i uczłowieczenia kultury po zakończeniu I wojny światowej. Następnie zwróciła uwagę na te środowiska, które dostrzegały znaczenie nauczania i wychowania religijnego dla życia społecznego oraz na formy realizacji edukacji religijnej w programach szkolnych, a także wpływ edukacji religijnej na poprawę życia społecznego. Na temat Funkcji inicjacji katechezy przedszkolnej $i$ wczesnoszkolnej w koncepcji Sofii Cavalletti wykład wygłosiła dr Barbara Surma. W oparciu o koncepcję wychowania religijnego Sofii Cavalletti La Catechesi del buon Pastore (Katecheza Dobrego Pasterza) przedstawiła zagadnienia dotyczące obrazu Boga, wychowania do modlitwy oraz wprowadzania dzieci w rzeczywistość sakramentalno-kościelną.

Trzecia sekcja przebiegała pod hasłem Wiara a rozwój człowieka. Prowadził ją ks. dr Dariusz Stępkowski. W jej ramach zostało wygłoszonych pięć referatów. Pierwszy wykład został poświęcony Znaczeniu cnót teologalnych w wychowaniu. Dr Iwona Jazurkiewicz w swoim wystąpieniu zwróciła uwagę na cnoty teologalne, które pochodzą od Boga, a ich nosicielem jest człowiek. Jej zdaniem w procesie wychowania znaczenie wiary, nadziei i miłości przebiega według porządku: 1) rozumienie danej cnoty, 2) postać biblijna jako wzór praktykowania danej cnoty, 3) użyteczność danej cnoty dla praktyki wychowania. Podkreśliła, że interpretacja teologiczna i pedagogiczna łączy kategorię cnoty ze szczęśliwością człowieka, będącą jego naturalnym pragnieniem. Na temat Wpływu edukacji religijnej na rozwój psychologiczny człowieka referat wygłosił dr Andrzej Molenda. Dowodził, że edukacja religijna może mieć zarówno pozytywny, jak negatywny wpływ na rozwój psychiczny istoty ludzkiej. Tezę o jej pozytywnym oddziaływaniu oparł na wynikach badań, prowadzonych przez dwóch badaczy: Davida Elkind i Johna McDargh. Natomiast problem niewłaściwej edukacji religijnej ukazał w kontekście nerwic eklezjogennych. Dr Ewa Dybowska swoje wystąpienie poświęciła Roli wiary w formacji (samowychowaniu) osoby w pedagogice ignacjańskiej. Pedagogika ignacjańska koncentruje się na poszukiwaniu Boga we wszystkim, a życie człowieka pragnie ukierunkować Ad Maiorem Dei Gloriam (,na większą chwałę Boga”). W swoim wystąpieniu dr Ewa Dybowska ukazała formację, czyli proces wydobywania obrazu Boga, który człowiek nosi w sobie, jako możliwość wychowawczego oddziaływania. W nurcie pedagogiki ignacjańskiej podstawę wychowania stanowi wiara. Jej zdaniem, wiara jest odpowiedzią na inicjatywę Boga wobec człowieka, wiara jest łaską i wiara jest możliwa poprzez osobistą relację (spotkanie) człowieka z Bogiem. Kolejny wykład został poświęcony Roli 
religii w salezjańskim wychowaniu prewencyjnym. Ks. dr Bogdan Stańkowski w swoim wystąpieniu ukazał wielką rolę religii w wychowaniu młodego człowieka. Jego zdaniem, zasada religijności stanowi fundament pełnego urzeczywistnienia osoby wychowanka oraz dostarcza wychowaniu spójną wizję antropologiczną człowieka. Podkreślił znaczenie wymiaru soteriologicznego, łączącego wartości wertykalne i horyzontalne, w procesie wychowania salezjańskiego oraz problem wychowania w perspektywie wielokulturowej. Wykład na temat Roli wiary $w$ wychowaniu moralnym $w$ świetle koncepcji wychowawczych o. Jacka Woronieckiego i filozofii o. Józefa Marii Bocheńskiego wygłosił dr Jarosław Horowski. Poprzez odwołanie się do poglądów o. Jacka Woronieckiego i filozofii o. Józefa Marii Bocheńskiego ukazał zawiązki moralności z wiarą. Zastanawiał się, czy rozwój moralny uzależniony jest od kontekstów światopoglądowych, czy jest od nich niezależny; jeżeli jest uzależniony, to czy rezygnując z edukacji religijnej, nie relatywizujemy moralności; jeżeli jest niezależny, to co sprawia, że mimo rezygnacji z edukacji religijnej moralność nie ulega relatywizacji.

Obrady czwartej sekcji koncentrowały się wokół zagadnienia Religia i religijność w kontekście wspótczesności. Jej moderatorem został ks. prof. Bogusław Milerski. Autorem pierwszego referatu Religijny fikcjonalizm jako wyzwanie dla pedagogiki religii była dr Agnieszka Salamucha. Przedmiotem swojego wystąpienia uczyniła religijny fikcjonalizm, będący stanowiskiem w sporze na temat miejsca religii w pluralistycznym pod względem religijnym oraz kulturowym społeczeństwie. Ukazała podstawowe założenia religijnego fikcjonalizmu oraz jego kontekst myślowy. Następnie przedstawiła argumenty za i przeciw religijnemu fikcjonalizmowi oraz konsekwencje jego przyjęcia dla teorii i praktyki pedagogiki religii. Dr hab. Kazimierz Skoczylas wygłosił referat na temat Wartości moralnych młodzieży ponadgimnazjalnej regionu konińskiego. Celem zaprojektowanego badania uczynił poznanie świata wartości młodzieży szkół ponadgimnazjalnych regionu konińskiego. Podkreślił, że zgromadzone wyniki są ważne ze względu na nauczanie religii w szkole oraz z uwagi na duszpasterskie oddziaływanie Kościoła katolickiego na młodzież dzisiaj oraz w przyszłości. Kolejny referat został poświęcony tematowi Religijność młodzieży a pluralistyczne społeczeństwo czeskie na poczatku XXI wieku. Dr Aniela Różańska podjęła próbę zrozumienia religijności w państwie czeskim na początku XXI wieku, badając młodzież z pogranicza czesko-polskiego. Na zaistniałą sytuację spojrzała z punktu widzenia dokonującej się sekularyzacji społecznej oraz pluralistycznych postaw religijnych. Przedostatni wykład Społeczne uwarunkowaniom rozwoju religijnego współczesnej młodzieży wygłosił dr Andrzej Łuczyński. W swoim wystąpieniu ukazał, jak czynniki społeczne (rodzina, szkoła, Kościół) kształtują rozwój religijny młodzieży. Zastanawiał się, czy społeczeństwo, 
w którym zaniedbywane jest wychowanie religijne, a często promowane antywartości, jest w stanie zaspokoić pragnienia i oczekiwania współczesnych młodych. Czy taka postawa ma znaczący wpływ na życie społeczne, moralne i religijne młodego pokolenia? Na temat Przestrzeni medialnej i przemian w procesie wychowania wykład wygłosiła dr Dorota Bis. W zaprezentowanym referacie ukazała wpływ przestrzeni medialnej na przemiany zachodzące w procesie wychowania, zwłaszcza w środowisku życia rodzinnego.

W czasie obrad sekcji pedagogiki religii poruszona została bardzo bogata tematyka dotycząca człowieka, religii i edukacji. Podkreślono znaczenie trwałych wartości opartych na chrześcijańskiej religii w procesie rozwoju i wychowania człowieka. Zastanawiano się nad rolą religii w pedagogice oraz nad edukacją religijną w perspektywie historycznej. Przedstawione zostały filozoficzne oraz teologiczne podstawy edukacji religijnej, a także poruszono zagadnienie dotyczące religii i edukacji religijnej w kontekście współczesności. $Z$ bogactwa treści, które zostały przedstawione podczas tej sekcji wypływa wniosek, że religia odgrywa bardzo ważną rolę w procesie całościowego wychowania człowieka. 